\title{
Foraging in Guanay cormorant and Peruvian booby, the major guano-producing seabirds in the Humboldt Current System
}

\author{
Henri Weimerskirch ${ }^{1, *}$, Sophie Bertrand ${ }^{2,3}{ }^{\text {, Jaime Silva }}{ }^{3}$, Charly Bost ${ }^{1}$, \\ Salvador Peraltilla ${ }^{3}$ \\ ${ }^{1}$ Centre d'Etudes Biologiques de Chizé, CNRS, 79360 Villiers en Bois, France \\ ${ }^{2}$ Institut de Recherche pour le Développement, Teruel No. 357 - Miraflores, Casilla 18-1209, Lima 18, Peru \\ ${ }^{3}$ Instituto del Mar del Perú, IMARPE, PO Box 22, Callao, Peru
}

\begin{abstract}
The Humboldt Current System is the most productive upwelling system globally in terms of fish and sustains huge populations of guano-producing birds as well as the world's largest single-species fishery targeting the Peruvian anchovy Engraulis ringens. Peruvian boobies Sula variegata and Guanay cormorants Phalacrocorax bougainvillii are the most abundant seabird species in the system and feed mainly on anchovies. By using high precision GPS and time-depth recorders, we compared the horizontal and vertical movements of the 2 species to examine whether segregation occurs between their foraging areas and whether there is any evidence for prey depletion close to large colonies. A simultaneous acoustic cruise in the foraging area of the 2 bird species estimated the vertical and horizontal distributions of anchovy schools. During the study period in austral spring 2008, the 2 bird species foraged in the same area, at relatively short distance from the colony (average, 19 to $20 \mathrm{~km}$ ). Both species foraged at similar times of the day, although Peruvian boobies tended to leave earlier in the morning and return later in the evening than did the cormorants. Foraging trips were similar in duration, distance covered and range. Peruvian anchovies were abundant and schools occurred at shallow depths (median, $7 \mathrm{~m}$; range, 3 to $34 \mathrm{~m}$ ), mainly to the north and west of the colony where foraging bouts of the 2 species overlapped extensively. Cormorants are mainly pelagic surface divers, diving at shallow depths (median, $4 \mathrm{~m}$ ) but reaching up to $32 \mathrm{~m}$ depth, and are thus able to track all the depths at which anchovies occurred during the study period. Peruvian boobies are plunge divers able to reach occasionally $10 \mathrm{~m}$ (median, $2 \mathrm{~m}$ ), and are thus able to reach only shallow anchovy schools. No sexspecific differences in horizontal or vertical movements occurred between males and females in the 2 species. We suggest that the absence of significant differences between horizontal movements of boobies and cormorants, the relative short duration of their trips and the high number of chicks fledged were probably explained by the high abundance and accessibility of anchovies. Differences may be exacerbated during years of low anchovy abundance or accessibility, especially El Niño years.
\end{abstract}

KEY WORDS: Peruvian anchovy $\cdot$ Telemetry $\cdot$ Phalacrocorax bougainvillii $\cdot$ Sula variegata Resale or republication not permitted without written consent of the publisher

\section{INTRODUCTION}

The Peruvian zone of the Humboldt Current System (HCS) is the most productive upwelling system globally and sustains the world's largest single species fishery targeting the Peruvian anchovy Engraulis ringens. It is also subject to great climatic variability and contrasting ecosystem scenarios be- 
tween years (Chavez et al. 2008). Reasons for such fish abundances are complex, and are still not yet well understood (Bakun \& Weeks 2008). The HCS is also well known for the massive concentrations of seabirds that breed in large colonies, which historically number hundreds of thousands of individuals in a single colony, representing one of the world's most spectacular aggregation of seabirds (Murphy 1936). The seabirds produce large quantities of guano that was a major source of fertilizers in the 19th century and is still exploited industrially, but at a much smaller scale. Guanay cormorants Phalacrocorax bougainvillii and Peruvian boobies Sula variegata are the main guano-producing species and breed on islands and headlands along the Peruvian coast. They rely mainly on Peruvian anchovies (Jordan 1967, Jahncke \& Goya 1998), which are also exploited by the huge fish-meal oriented anchovy fishery.

Over the past 50 yr, Guanay cormorants have dramatically decreased from ca. 21 million to 2 million individuals, whereas Peruvian boobies have remained relatively stable at ca. 2 million birds (Goya 2000). Reasons for the decline of Guanay cormorants have been related to successive El Niño events and competition with the industrial fishery that developed in the 1950s (Tovar et al. 1987). The fact that the populations of cormorants and boobies show contrasting trends, although the 2 species breed together and feed on the same prey, suggests that differences in their foraging ecology may be implicated in the trends of the species. A better knowledge of their foraging ecology may help to understand the different population dynamics of the 2 species.

Guanay cormorants nest in extremely dense colonies and are social foragers, forming endless columns moving from colonies to feeding grounds, whereas Peruvian boobies breed in large, but less dense colonies (Murphy 1936, Duffy 1983). Guanay cormorants use colonies as recruitment centres, recruiting congeners through a meeting point off the colonies (Weimerskirch et al. 2010). Conversely boobies leave colonies mainly solitarily (Weimerskirch et al. 2010) and can hunt solitarily as well as in groups (Duffy 1983, H. Weimerskirch pers. obs.). However, it remains to be clarified how the 2 species, feeding on the same prey and at the same time of the year, can co-exist in such large numbers and whether the 2 species show some form of segregation in their foraging ecology at sea (Pianka 1969). The 2 species may forage at different times of the day or in different places, or exploit anchovies in different ways, for example diving at distinct depth ranges. The alterna- tive hypothesis is that prey abundance is not limiting, and thus segregation does not occur. Compared with other species in their respective families, Peruvian boobies and Guanay cormorants have high clutch sizes, especially boobies, which have the highest clutch sizes within their family (Nelson 1978), and can fledge large numbers of chicks, up to 4 for boobies, and thus have to provide large quantities of food daily.

To test these different hypotheses, we studied the foraging ecology of these 2 species on an island in the Pacific Ocean off central Peru where they breed in sympatry in large numbers. The aim of the study was to compare the foraging movements and diving behaviour of the 2 species to examine whether they show segregation or overlap in the foraging zones and to examine differences in the foraging movements. We also examined whether the 2 species utilise the same depths and underwater search behaviour to capture anchovies. Finally we interpreted the horizontal and vertical movements of these 2 top predators in relation to the distribution of their prey, which was estimated during a concurrent oceanographic cruise. Since both bird species show sex-specific size differences, with Peruvian boobies showing reversed sexual dimorphism, we also considered sex differences within species as a potential source of heterogeneity in foraging strategies.

\section{MATERIAL AND METHODS}

\section{Study site and field methods}

The study was carried out between 22 November and 10 December 2008 on Isla Pescadores $\left(11.775^{\circ} \mathrm{S}\right.$, $77.265^{\circ} \mathrm{W}$ ), a small island located $7.5 \mathrm{~km}$ off the central coast of Peru. At this time of the year, both species were rearing small to large chicks. Peruvian boobies had between 1 and 3 chicks per nest (mean $\pm \mathrm{SD}=2.0 \pm 0.54, \mathrm{n}=50$ nests), Guanay cormorants had between 1 and 4 chicks $(2.1 \pm 0.3, \mathrm{n}=21)$. About 240000 Guanay cormorants and 41000 Peruvian boobies were breeding at this time on the island (AgroRural pers. comm.).

Birds attending their chicks on the nest were selected randomly in the colony and captured using a fishing pole equipped with a noose. At first capture, each bird was banded with a stainless steel identification band, measured (culmen length using dial calipers and wing length using a ruler) and weighed $( \pm 20 \mathrm{~g})$ in a bag with a Pesola balance. They were 
marked with a colour marking used for cattle on the head (boobies) or the chin (cormorants) for identification at a distance within the colony. Boobies were sexed by vocal call (when captured, males have a higher pitched call than females, Nelson 1978). Because male cormorants are larger than females, we used the relationship between mass and wing length to separate sexes: males are heavier than $2100 \mathrm{~g}$ and have a wing length $>305 \mathrm{~mm}$, whereas females have shorter wings and are lighter (Nelson 2006).

We equipped 51 Peruvian boobies (average mass, $1520 \mathrm{~g}$ ) with Gipsy GPS recorders (25 to $30 \mathrm{~g}$, Technosmart) and 20 Guanay cormorants (2150 g) with MiniGPSlog recorders (30 g, Earth and Ocean GPS). The GPS recorded locations at $1 \mathrm{~s}$ or at $30 \mathrm{~s}$ intervals and were attached with Tesa tape to the tail feathers (boobies) or to the back feathers (cormorants) for 1 to 9 successive trips, and provided a total of 165 and 46 foraging trips for boobies and cormorants, respectively. All birds were recaptured except for 1 cormorant, but we were not able to retrieve data from 2 GPS recorders deployed on cormorants and from 3 GPS recorders from boobies. In addition all cormorants and 15 boobies fitted with GPS recorders were also equipped with time-depth recorders (TDRs) that recorded at $1 \mathrm{~s}$ intervals and at $0.1 \mathrm{~s}$ intervals during immersion $(3 \mathrm{~g}$; resolution, $4 \mathrm{~cm}$; G5 CEFAS Technology); the TDRs were fixed on the bird's leg with a metal band.

\section{Foraging movement analysis}

From the GPS data we calculated basic foraging parameters such as distance covered and speed between locations, time spent foraging and maximum foraging range, as well as the bearings at departure from the colony. The time series data extracted from TDRs and GPS recorders were merged into a single file to determine the zones of feeding indicated by the dive behaviour of birds or the simultaneous use of area restricted search (ARS) behaviour, when birds increased sinuosity or take off and land actively. Since the movements of the 2 species are typical, with linear phases of commuting until the birds start ARS (boobies) or dive actively (cormorants) (Weimerskirch et al. 2010), the determination of foraging bout zones was straightforward and did not required complex analysis. We considered zones of foraging bouts to be zones used by Guanay cormorants when (1) a series of dives occurred for birds fitted with GPS recorder and TDR or for birds fitted only with GPS or where (2) flight speeds in these zones were $<10 \mathrm{~km} \mathrm{~h}^{-1}$ indicating birds were not in flight (Weimerskirch et al. 2005) and intervals between GPS locations were more than twice the recording interval, i.e. indicating that the GPS signal was lost during dives. We were able to control for lost signals during dives on birds fitted with a GPS recorder and TDR, because on these series of dives, the GPS localisations would be systematically lost for extended periods and would indicate periods of low speeds, whereas periods of low speed in which a normal frequency of positioning (no loss of satellite signal) was recorded, indicated that the bird was sitting on the water. When diving in series, cormorants do not use typical movements associated with horizontal ARS (see Results, Fig. 2). For boobies, the foraging bout was different, since birds are in flight and use typical ARS patterns where they increase sinuosity, dive frequently and spend short periods on the water. Since boobies dive at lower depths and during shorter periods than do cormorants (see Results), satellite signals were lost less frequently and for shorter periods.

We used the fixed kernel method (Worton 1995) and the least square algorithm (Seaman \& Powell 1996) to estimate the contours of level densities 25, 50 and $90 \%$ for the foraging bout positions (Wood et al. 2000). The spatial overlap between the foraging bouts kernels from the 2 species was calculated with R (R Development Core Team 2006), using the library 'adehabitat'.

\section{Diving behaviour}

TDRs were fitted on 15 boobies and recorded diving behaviour for 655 dives during a period of $281 \mathrm{~h}$. Diving behaviour was recorded on 11 instrumented cormorants for $293 \mathrm{~h}$ (2652 dives recorded). We used MT software (Jensen Software) to analyze the main dive parameters as follows: time of the beginning of the dive, dive duration, rate of descent, maximal depth, bottom depth and duration, total way vertical at the bottom, number of undulations at depth (wiggles) and amplitude up and down, rate of ascent and duration of post-dive recovery. A dive was considered to occur only if it was deeper than $0.5 \mathrm{~m}$ (cormorants) or $0.3 \mathrm{~m}$ (boobies) in accordance with the at-sea behaviour of each species.

Bottom time was defined as the time spent in the zone below $80 \%$ of the maximum depth (Kato et al. 2006). Wiggles were defined as elements of the dive profile during which $>3$ successive points had vertical speed close to $0 \mathrm{~m} \mathrm{~s}^{-1}$ (Halsey et al. 2007). Wiggles 
corresponded to particular patterns in the dive profile over time where an increase in depth over time alternated with a decrease in depth and then back to an increase in depth. This created a short event in the dive profile that was concave in shape. Post-dive intervals $>400 \mathrm{~s}$ were excluded from calculations of diving efficiency as suggested by the graphical analysis of post-dive distribution (Kooyman \& Kooyman 1995).

To analyse the relationship between diving parameters we used data sets giving an equal statistical weight to each individual. For this, we randomly selected the same number of dives per bird by using the smallest number obtained (55 dives) for statistical analyses. Because cormorants dive in bouts, boutending criteria were identified using a log-survivor curve of post-dive intervals (Watanuki et al. 2008). This corresponded in Guanay cormorants to an inflexion point of $120 \mathrm{~s}$, allowing us to define discrete diving bouts. We calculated intra-depth zone (IDZ) indices to determine whether a cormorant tended to dive serially during bouts to a similar depth (Tremblay \& Cherel 2000). A dive was considered as an IDZ dive when the maximum depth of the foraging dive was $\pm 10 \%$ of the maximum depth of the preceding dive.

\section{Prey distribution}

Instituto del Mar del Peru (IMARPE) performed a $3 \mathrm{~d}$ long acoustic survey (2 to 5 December 2008) with RV 'José Olaya B.' (41 m length) around Islas Pescadores during the bird-tracking experiment. The study area extended between Punta Salinas $\left(11^{\circ} 17^{\prime} \mathrm{S}\right)$ and Callao $\left(12^{\circ} 08^{\prime} \mathrm{S}\right)$, and from 0.37 to $37-74 \mathrm{~km}$ from the coast. Acoustic data were collected using a hull-mounted tri-frequency $(38,120$ and $200 \mathrm{kHz})$ scientific echo sounder (EK-60, Kongsberg, Simrad AS). Echo sounder calibration was performed according to Foote et al. (1987). Survey tracks consisted of 11 parallel cross-shore transects, distant of $9.3 \mathrm{~km}$, with a target vessel speed of $18.5 \mathrm{~km} \mathrm{~h}^{-1}$. The water column was sampled down to depths of $500 \mathrm{~m}$. Biological sampling of organisms observed by acoustic methods was performed using a pelagic trawl (Engel 124/1800, $12 \mathrm{~mm}$ cod end mesh), which allowed identification of the species found from the echo traces and biometric studies. Two distinct databases were built from the acoustic data. (1) Nautical-areabackscattering coefficients (NASC or $\mathrm{s}_{\mathrm{A}}$, see Maclennan et al. 2002 for acoustic units), an index of fish abundance, were recorded along survey tracks at each $1.85 \mathrm{~km}$ long georeferenced elementary distance sampling unit (ESDU) (Simmonds \& Maclennan 2005). This database was used to compute 2 global indexes (see Marchal 1990 and Bertrand et al. 2002, 2004 for detailed information on those indexes) describing anchovy as prey field: acoustic index of abundance $\left(\mathrm{s}_{\mathrm{A}}+\right)$ and index of space occupation by the biomass (ISO). (2) Anchovy schools along survey tracks were identified with a specific module from Echoview software (SonarData), which provided their mean depth. Only diurnal data were retained in this 'school database' as anchovy aggregations disperse in layers at night and seabirds foraged only during daytime.

We provide here the centroid of the anchovy schools encountered. The acoustic measure of school depth is affected by 2 biases: (1) the base of the echo sounder is not at the surface but at $3.4 \mathrm{~m}$ depth for the RV 'José Olaya B.' and (2) fish avoid the vessel. In the case of the Peruvian anchovy, vertical avoidance is minor, $\sim 5 \mathrm{~m}$, and horizontal avoidance is absent (Gerlotto et al. 2004). So from the original depth measurement, we would normally add echo sounder depth and subtract avoidance depth. However, since those 2 biases globally compensate each other, the original measured depth is usually used and has an error of about $2 \mathrm{~m}$.

\section{Statistical analysis}

In the analysis of individual foraging trips, because some individuals were tracked for multiple successive trips, we analysed foraging parameters (maximum range, time spent foraging) using mixed effect ANOVA (module VEPAC in STATISTICA 8) to consider issues of pseudoreplication. Foraging parameters were taken as dependent variables, species were added to the model as fixed factors and individual bird was included as a random factor. Frequencies of occurrence were compared using chi-square tests. Time was given as local time, i.e. GMT $-5 \mathrm{~h}$, with sunrise occurring at 05:40 h, sunset at 18:15 $\mathrm{h}$ and civil twilight occurring between 05:10 and 18:43 h. Parametric tests were used to compare diving performances between sexes after checking for the normality of the distribution and homogeneity of the variances. To test the differences in diving performances between individuals we used a Generalised Linear Model in which the individuals were used as the factors and the depth and bouts duration as explanatory variables (Wanless et al. 1999). 


\section{RESULTS}

\section{Foraging time}

Both species foraged only during the day and spent the night on land, on the nest or nearby. While rearing small to medium size chicks, the 2 species made between 1 to 4 foraging trips at sea per day. Departures and returns were spread throughout the day (Fig. 1). Guanay cormorants departed and returned to the colony during daytime, with a first peak of departure after sunrise (Fig. 1). They all returned to the colony before night. Boobies tend to start leaving colonies earlier than cormorants, at first light of day, and the last returns occurred early in the evening (Fig. 1).

\section{Foraging movements}

The duration of foraging trips was longer for cormorants than for boobies, but the maximum range and total distance covered were similar for the 2 spe-

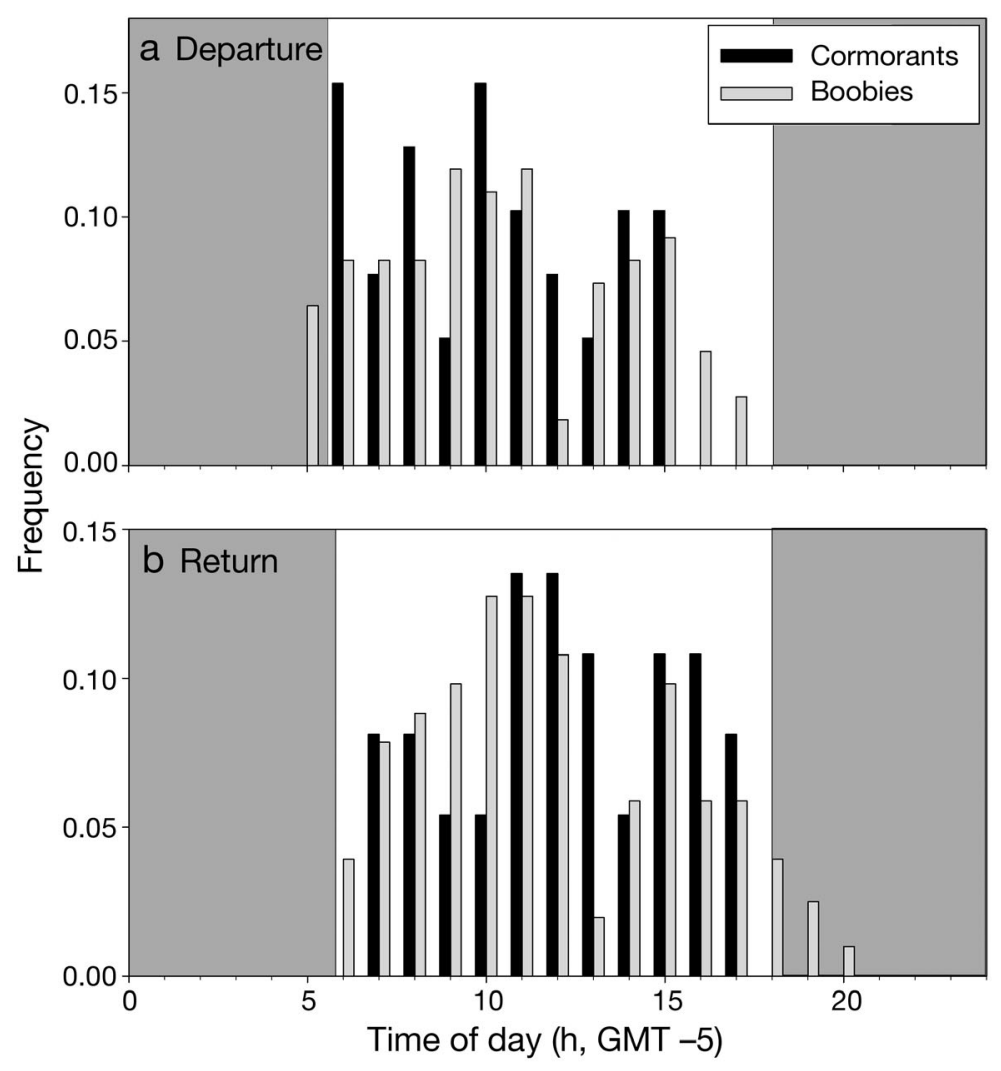

Fig. 1. Phalacrocorax bougainvillii and Sula variegata. Distribution of (a) departure times from and (b) return times to the colony of Guanay cormorants (घ) and Peruvian boobies $(₫)$. Grey boxes = nighttime cies (Table 1). Cormorants spent significantly more time on the water and diving than did boobies, which spent a larger proportion of their foraging trips in flight (Table 1). Flight speeds were slightly higher for cormorants than for boobies (Table 1). There was no sex-specific difference in foraging parameters of cormorants. For boobies, males had a slightly longer maximum range and covered longer total distances than did females (Tables 1).

In both species, the foraging trips consisted of an outward relatively straight leg, one or several foraging bouts and a return phase (Fig. 2). In cormorants, foraging bouts appeared as a series of diving events, in which birds surface-dived serially in a line and did not loop in flight. Boobies, however, circled certain zones where they plunge-dived regularly (Fig. 2, A\&B). For some individuals, no foraging bouts were observed. The number of foraging bouts per trip was higher in cormorants than in boobies, which generally had a single foraging bout (Table 1). Foraging bouts were mainly in offshore pelagic waters, and only $8 \%$ and $5.1 \%$ of the foraging bouts for Guanay cormorants ( $\mathrm{n}=75$ foraging bouts) and Peruvian boobies $(\mathrm{n}=116)$, respectively, occurred in coastal waters (within $500 \mathrm{~m}$ of the coast) (Fig. 3). Foraging bouts were located generally at the maximum range of the trip (Fig. 2).

\section{Foraging zones}

Foraging zones of Guanay cormorants and Peruvian boobies, indicated by foraging bouts, were located in all directions around Isla Pescadores, with higher concentrations to the west and northwest (Fig. 3a). There were no foraging bouts within $5 \mathrm{~km}$ of Isla Pescadores and they were rare within $10 \mathrm{~km}$ (Fig. 3a). The 90, 50 and 25\% kernel density contours of the foraging bouts from the 2 species overlapped extensively (overlaps of 92.9, 75 and $61.9 \%$, respectively), indicating that the 2 species were foraging in the same areas (Fig. $3 b, c)$.

\section{Diving behaviour}

The bulk of dives occurred during the daytime, but some differences between species occurred in the timing of diving. For Guanay cormorants, diving activity was strictly diur- 
Table 1. Phalacrocorax bougainvillii and Sula variegata. (a) Species differences and (b) sex differences in foraging characteristics of Guanay cormorants (GC) and Peruvian boobies (PB) fitted with GPS recorders, and summary statistics for both species. Means $\pm \mathrm{SD}(\mathrm{n})$

\begin{tabular}{|c|c|c|c|c|c|c|}
\hline \multirow{2}{*}{$\begin{array}{l}\text { Foraging characteristic } \\
\text { a Species differences }\end{array}$} & \multicolumn{3}{|c|}{ Species (a) or sex (b) } & \multirow[t]{2}{*}{$F$} & \multirow[t]{2}{*}{$\mathrm{df}$} & \multirow[t]{2}{*}{$\mathrm{p}$} \\
\hline & & Guanay cormorant & Peruvian booby & & & \\
\hline Mass (g) & & $2138 \pm 132(20)$ & $1564 \pm 160(33)$ & 250 & 1,49 & $<0.0001$ \\
\hline Wing length (mm) & & $302 \pm 9.0(21)$ & $398 \pm 14(49)$ & 1548 & 1,66 & $<0.0001$ \\
\hline Duration of foraging trips (h) & & $2.0 \pm 0.8(38)$ & $1.4 \pm 1.8(104)$ & 8.7 & 1,39 & 0.0048 \\
\hline Foraging range $(\mathrm{km})$ & & $18.9 \pm 6.1(38)$ & $20.2 \pm 11.5(104)$ & 0.5 & 1,39 & 0.480 \\
\hline Distance covered $(\mathrm{km})$ & & $46.5 \pm 16.4(38)$ & $50.7 \pm 29.4(98)$ & 0.9 & 1,39 & 0.340 \\
\hline Flight speed $\left(\mathrm{km} \mathrm{h}^{-1}\right)$ & & $49.5 \pm 2.0(27)$ & $47.0 \pm 2.8(41)$ & 19.1 & 1,20 & 0.0005 \\
\hline Percentage time on water $(\%)$ & & $38.4 \pm 17.6(27)$ & $10.4 \pm 9.1(40)$ & 46.0 & 1,20 & $<0.001$ \\
\hline Number of foraging bouts & & $2.1 \pm 1.3(36)$ & $0.96 \pm 0.44(100)$ & 43.0 & 1,38 & $<0.001$ \\
\hline Mean maximum depth (m) & & $6.3 \pm 4.9(2492)$ & $1.8 \pm 1.4(593)$ & 18.5 & 1,20 & $<0.001$ \\
\hline b Sex differences & & Female & Male & $F$ & $\mathrm{df}$ & $\mathrm{p}$ \\
\hline Mass (g) & $\begin{array}{r}\mathrm{GC} \\
\mathrm{PB}\end{array}$ & $\begin{array}{l}1983 \pm 168 \\
1677 \pm 105\end{array}$ & $\begin{array}{l}2292 \pm 180 \\
1411 \pm 67\end{array}$ & $\begin{array}{l}15.0 \\
68.7\end{array}$ & $\begin{array}{l}1,18 \\
1,31\end{array}$ & $\begin{array}{r}0.001 \\
<0.001\end{array}$ \\
\hline Wing length (mm) & $\begin{array}{r}\mathrm{GC} \\
\mathrm{PB}\end{array}$ & $\begin{array}{l}297 \pm 10 \\
407 \pm 10\end{array}$ & $\begin{array}{l}307 \pm 4 \\
388 \pm 8\end{array}$ & $\begin{array}{r}8.8 \\
46\end{array}$ & $\begin{array}{l}1,19 \\
1,47\end{array}$ & $\begin{array}{r}0.008 \\
<0.001\end{array}$ \\
\hline Duration of foraging trips $(\mathrm{h})$ & $\begin{array}{r}\mathrm{GC} \\
\mathrm{PB}\end{array}$ & $\begin{array}{l}2.1 \pm 0.8 \\
1.1 \pm 0.53\end{array}$ & $\begin{array}{l}2.0 \pm 0.8 \\
1.6 \pm 2.3\end{array}$ & $\begin{array}{l}0.04 \\
17.0\end{array}$ & $\begin{array}{l}1,12 \\
1,25\end{array}$ & $\begin{array}{l}0.842 \\
0.144\end{array}$ \\
\hline Foraging range $(\mathrm{km})$ & $\begin{array}{r}\mathrm{GC} \\
\mathrm{PB}\end{array}$ & $\begin{array}{l}17.1 \pm 5.2 \\
18.0 \pm 8.2\end{array}$ & $\begin{array}{l}20.5 \pm 6.5 \\
22.0 \pm 13.5\end{array}$ & $\begin{array}{l}2.6 \\
4.7\end{array}$ & $\begin{array}{l}1,12 \\
1,25\end{array}$ & $\begin{array}{l}0.134 \\
0.049\end{array}$ \\
\hline Distance covered $(\mathrm{km})$ & $\begin{array}{r}\mathrm{GC} \\
\mathrm{PB}\end{array}$ & $\begin{array}{l}44.3 \pm 18.2 \\
45.1 \pm 21.0\end{array}$ & $\begin{array}{l}48.5 \pm 15.6 \\
55.2 \pm 34.3\end{array}$ & $\begin{array}{r}0.44 \\
5.3\end{array}$ & $\begin{array}{l}1,12 \\
1,25\end{array}$ & $\begin{array}{l}0.520 \\
0.046\end{array}$ \\
\hline Flight speed $\left(\mathrm{km} \mathrm{h}^{-1}\right)$ & $\begin{array}{r}\mathrm{GC} \\
\mathrm{PB}\end{array}$ & $\begin{array}{l}49.1 \pm 2.0 \\
47.6 \pm 3.0\end{array}$ & $\begin{array}{l}49.8 \pm 1.9 \\
46.8 \pm 2.7\end{array}$ & $\begin{array}{l}0.9 \\
0.6\end{array}$ & $\begin{array}{r}1,8 \\
1,10\end{array}$ & $\begin{array}{l}0.388 \\
0.458\end{array}$ \\
\hline Percentage time on water $(\%)$ & $\begin{array}{r}\mathrm{GC} \\
\mathrm{PB}\end{array}$ & $\begin{aligned} 42 & \pm 17.0 \\
12.5 & \pm 9.0\end{aligned}$ & $\begin{array}{c}35.0 \pm 18.1 \\
9.8 \pm 9.2\end{array}$ & $\begin{array}{l}0.5 \\
0.6\end{array}$ & $\begin{array}{r}1,8 \\
1,10\end{array}$ & $\begin{array}{l}0.510 \\
0.437\end{array}$ \\
\hline Number of foraging bouts & $\begin{array}{r}\mathrm{GC} \\
\mathrm{PB}\end{array}$ & $\begin{array}{l}1.7 \pm 1.2 \\
0.9 \pm 0.4\end{array}$ & $\begin{array}{l}2.5 \pm 1.2 \\
1.0 \pm 0.4\end{array}$ & $\begin{array}{l}4.5 \\
0.2\end{array}$ & $\begin{array}{r}1,9 \\
1,25\end{array}$ & $\begin{array}{l}0.069 \\
0.645\end{array}$ \\
\hline Mean maximum depth (m) & $\begin{array}{r}\mathrm{GC} \\
\mathrm{PB}\end{array}$ & $\begin{array}{l}1.7 \pm 1.4 \\
5.7 \pm 4.3\end{array}$ & $\begin{array}{l}2.4 \pm 1.2 \\
8.2 \pm 5.7\end{array}$ & $\begin{array}{l}3.3 \\
2.2\end{array}$ & $\begin{array}{r}1,11 \\
1,8\end{array}$ & $\begin{array}{l}0.097 \\
0.169\end{array}$ \\
\hline
\end{tabular}

nal (earliest dive starting at 06:09 $\mathrm{h}$, latest dive at 19:03 h). Cormorants exhibited 2 peaks of diving activity: one late in the morning (about $40 \%$ of dives) and another one at mid-afternoon (30\%) (Fig. 4). Diving activity of boobies occurred from sunrise to sunset with $15 \%$ occurring during periods of twilight. A marked peak of diving activity was observed in the afternoon from 16:00 to 17:00 h (Fig. 4).

Guanay cormorants performed relatively shallow dives, mostly between 2 and $8 \mathrm{~m}$, and a distinct diving mode occurred at $4 \mathrm{~m}$ depth. No bird dived deeper than $32 \mathrm{~m}$ (Fig. 5). Diving depths differed among sexes; males dived deeper (GLM: $F_{11,684}=$ 101.1, $\mathrm{p}<0.00001$ ) and longer (GLM: $F_{11,684}=156, \mathrm{p}<$ $0.00001)$ than females. The diving frequency was high $\left(12.3 \pm 6.1\right.$ dives $\left.\mathrm{h}^{-1}\right)$, and birds performed numerous diving bouts during each trip (Fig. 6) at similar depths (mean duration, $10.27 \pm 09.19 \mathrm{~min}$ ). The duration of diving bouts was highly variable among the individuals (1-way ANOVA: $F_{11,264}=22.54$ ).

The dive profiles showed a somewhat complex phase at the bottom (Fig. 6). Overall the time spent at the bottom of the dives was generally short (mean value ranged between 4 and $14 \mathrm{~s}$ according to the individuals). During the descent and bottom phase of the dive, high-frequency recordings showed constant oscillations corresponding to movements of birds propelled by their feet being pushed to the surface because of buoyancy (Fig. 6b).

Being plunge divers, diving depths of Peruvian boobies were shallower than those of cormorants, and dives did not occurr in bouts, but intermittently (Fig. 7a). Most (97.5\%) observed foraging efforts were plunge dives, 'spike' shaped with a direct descent and ascent phase and no bottom phase (Fig. 7b). 


\section{A Guanay cormorant}
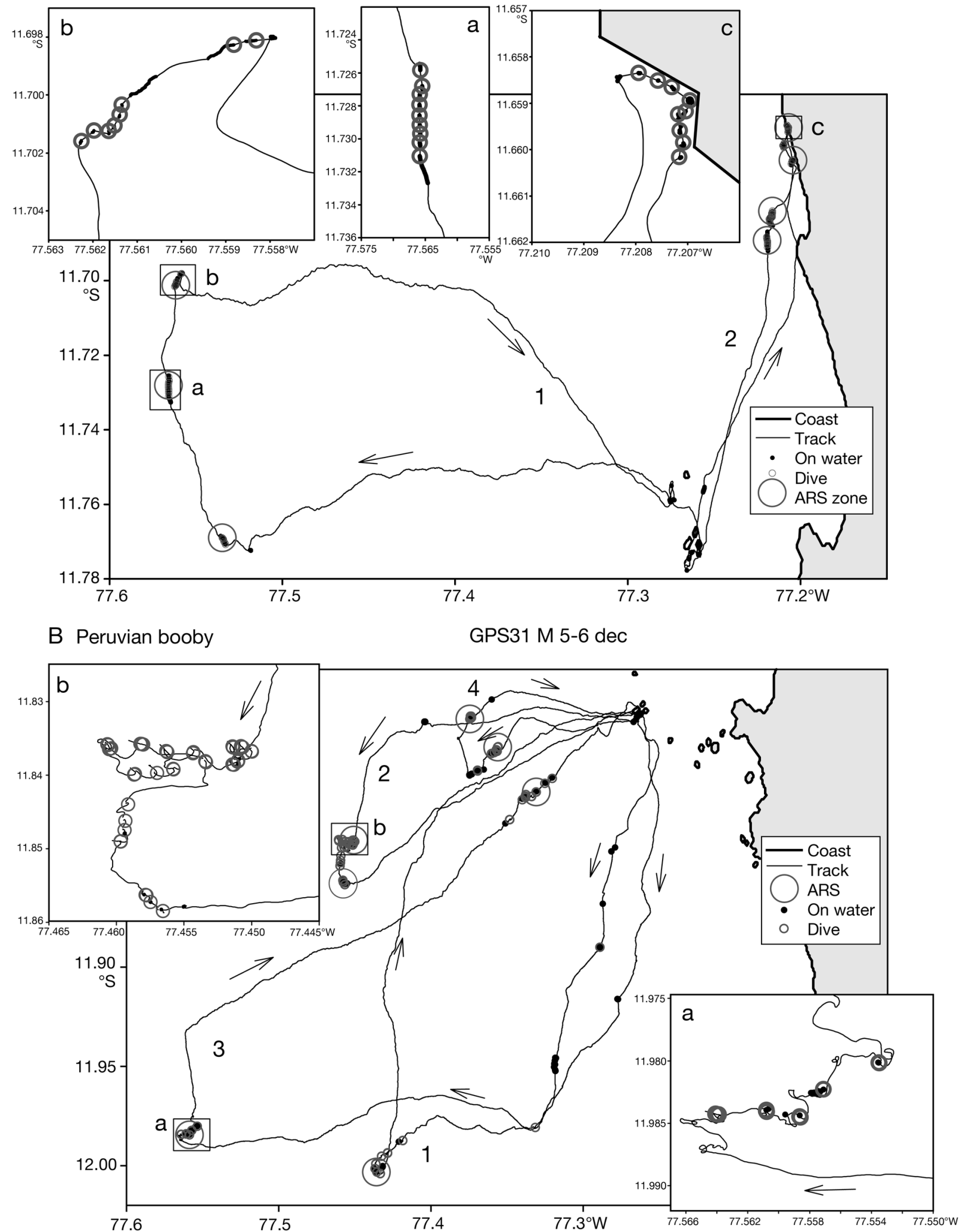

Fig. 2. Phalacrocorax bougainvillii and Sula variegata. Successive foraging trips of (A) a Guanay cormorant (2 trips: 1 pelagic, 2 coastal) and (B) a Peruvian booby (4 successive pelagic trips, 1 to 4 ), with enlargement of foraging zones. Symbols on tracks: $\bullet$ = location of landing on water, $\mathrm{O}=$ area restricted search (ARS) zones, o = dive events 


\section{Prey distribution}

The acoustic survey consisted of 413 ESDUs 1.85 $\mathrm{km}$ in length, and anchovy biomass in the area (Fig. 8) was estimated by IMARPE to be $3470000 \mathrm{t}$. The acoustic index of anchovy abundance $\left(\mathrm{s}_{\mathrm{A}}+\right)$ was $1476 \mathrm{~m}^{2} 1.85 \mathrm{~km}^{-2}$, and the index of the spatial concentration of the biomass (ISO) was 0.53. The same

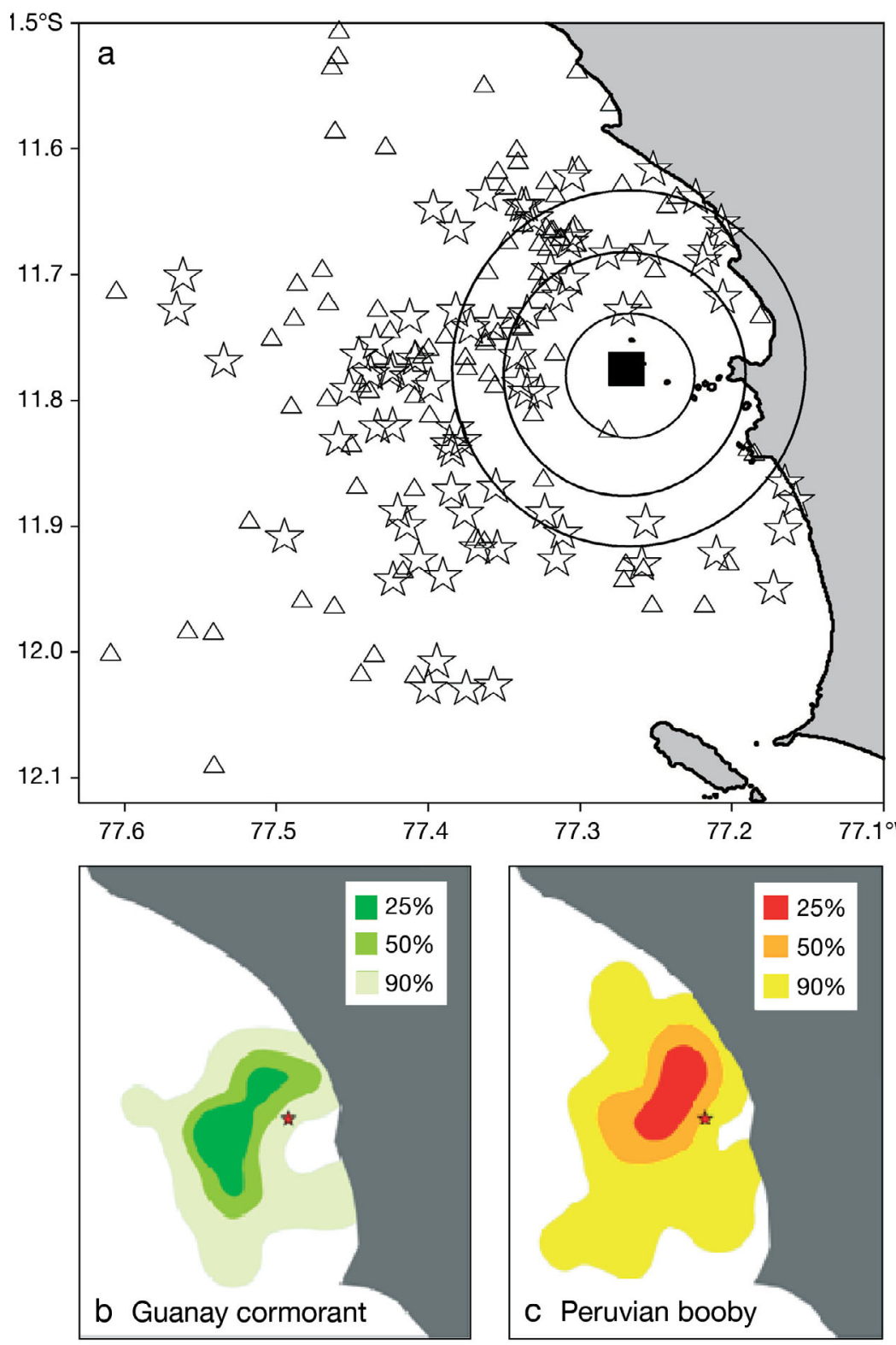

Fig. 3. Phalacrocorax bougainvillii and Sula variegata. (a) Distribution of foraging bouts of Guanay cormorants ( $\downarrow$ ) and Peruvian boobies $(\Delta)$ during the period from 24 November to 7 December 2008. Isla Pescadores is indicated by $\mathbf{\square}$, with concentric circles showing 5, 10 and $15 \mathrm{~km}$ radii around the colony. (b,c) Bottom density contour probability polygons (25, 50 and $90 \%$ ) are derived from kernel estimates of the foraging bouts of (b) Guanay cormorants (light to dark green) and (c) Peruvian boobies (yellow to red). $\star=$ Isla Pescadores indices were computed in Bertrand et al. (2005) for 36 acoustic surveys off Peru between 1984 and 2003, allowing us to interpret the values we obtained in 2008. The index $\mathrm{s}_{\mathrm{A}}+$ for those 36 surveys ranged between 51 and 2751, with the median at $495 \mathrm{~m}^{2} 1.85^{-2}$. Thus, Peruvian anchovies around Pescadores were relatively abundant during the tracking experiment. The index ISO for the 36 surveys was between 0.01 and 0.55 , with the median at 0.25 . Anchovy biomass was widely distributed in the area surrounding Pescadores, providing a potentially good horizontal availability for seabirds. Foraging bouts were concentrated in the general area of high anchovy abundance (Fig. 8). The Echoview software identified 876 anchovy aggregations along transects for daytime in the Pescadores area. The centroid of the schools ranged between 3.10 and $34.50 \mathrm{~m}$ depth, with the median at $7.43 \mathrm{~m}$ (Fig. 5). Guanay cormorants, with observed dives up to $32 \mathrm{~m}$, were able to exploit $\sim 100 \%$ of anchovy aggregations. Boobies, which had maximum observed dives to $10 \mathrm{~m}$, could attain about $80 \%$ of the anchovy aggregations, but the median depth of $2 \mathrm{~m}$ indicates that they generally exploited only the shallowest schools or the upper parts of deeper schools (Fig. 5).

\section{DISCUSSION}

The HCS is a very productive upwelling system that is subject to high interannual variability (Chavez et al. 2003). Compared with other upwelling systems it holds similar numbers of seabird species but larger numbers of individuals (Crawford et al. 2006), probably in relation to the high abundance of Peruvian anchovy. The study was carried out during a period of moderate negative sea surface temperature anomaly $\left(-0.4^{\circ} \mathrm{C}\right)$; Peruvian anchovies weres abundant and available horizontally and vertically around Isla Pescadores, suggesting that foraging conditions were favourable for piscivorous bird species with- 


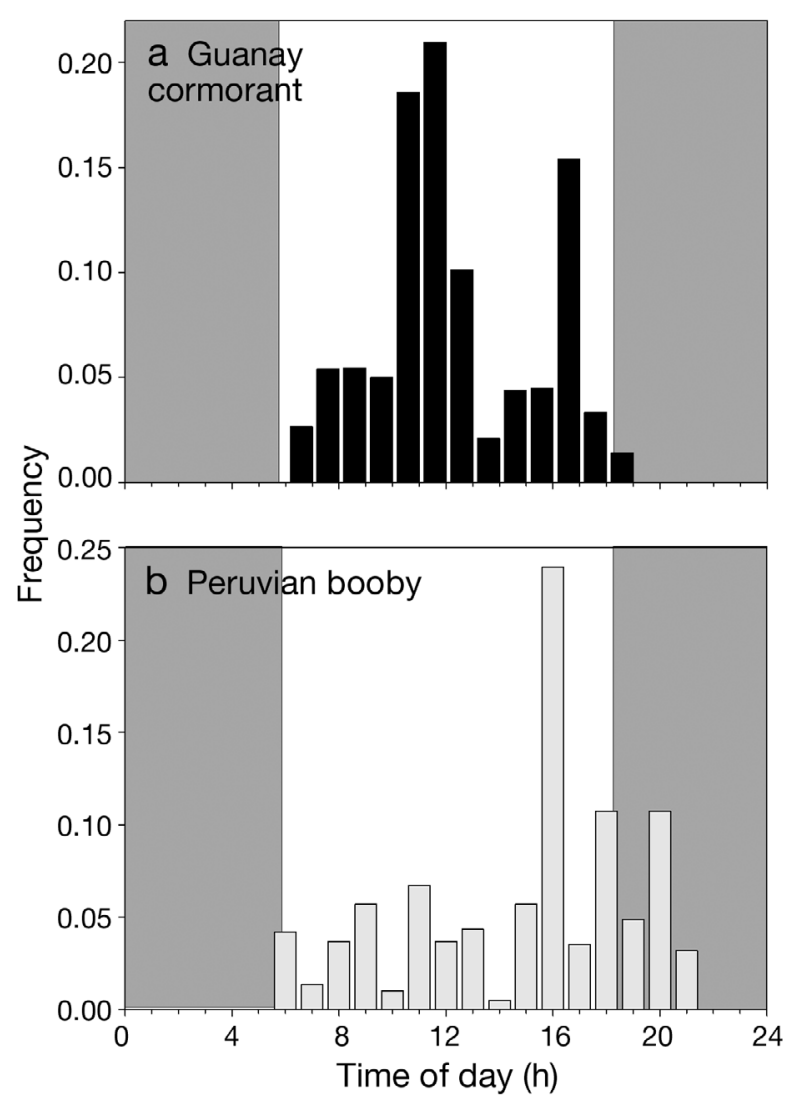

Fig. 4. Phalacrocorax bougainvillii and Sula variegata. Timing of diving in Guanay cormorants (a) and Peruvian boobies (b). Grey boxes = nighttime

in their foraging range. Most foraging trips taken by Guanay cormorants and Peruvian boobies encountered prey as indicated by the presence of hunting episodes in the large majority of trips and the regurgitation of anchovies by returning birds. The observation that foraging bouts were located generally at the maximum range of the trip suggests also that when birds had found a food patch, they would not search for another one because they had caught enough prey. However, several clear differences exist between the 2 species.

\section{Timing of foraging}

Both species are visual hunters and forage mainly during daytime, in contrast with the third guano-producing bird, the Peruvian pelican Pelecanus thagus, which forages mainly at night for the same prey (Zavalaga et al. 2011), although it may forage during the day in some circumstances (Duffy 1983). Thus, a partial segregation between pelicans and the 2 major guano-producing birds occurs in terms of timing of
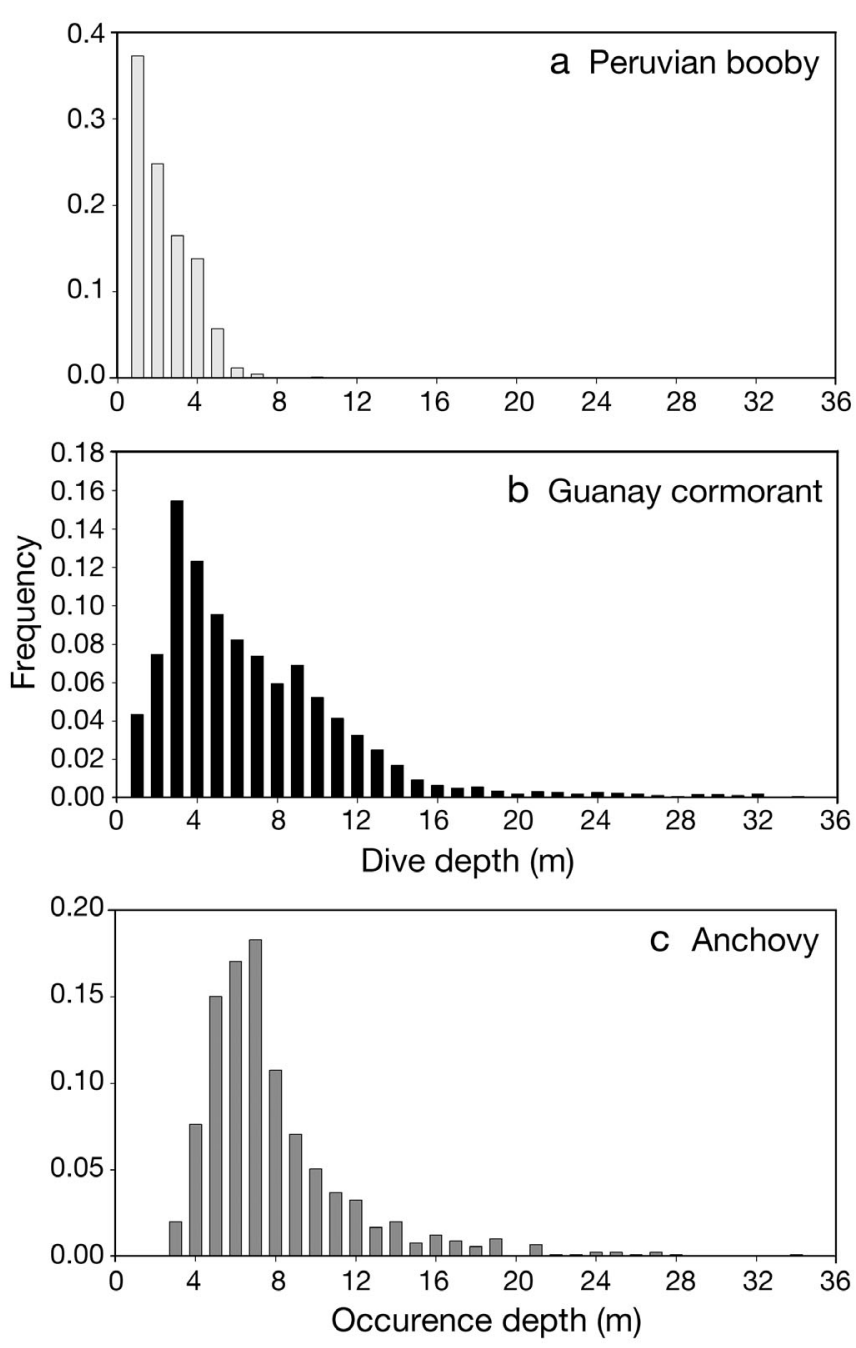

Fig. 5. Sula variegata, Phalacrocorax bougainvillii and Engraulis ringens. Frequency of dive depths attained by Peruvian boobies (a) and Guanay cormorants (b), and frequency distribution of depths of Peruvian anchovy schools during daytime estimated by acoustic survey and net captures (c)

foraging. Although no real segregation in terms of timing of foraging occurs between the 2 species, boobies appear to leave colonies earlier and return later from foraging trips than the cormorants; portions of the trips occur during hours of darkness, mainly for the return part of the commuting. However, a small number of dives occurred before sunrise and after sunset, probably when light conditions still allowed visual detection of prey. Boobies leave the colonies solitarily (Weimerskirch et al. 2010), whereas Guanay cormorants leave in large groups, using colonies as a recruitment centre and recruiting congeners through a meeting point or compass raft at sea off the colonies (Weimerskirch et al. 2010). The establish- 

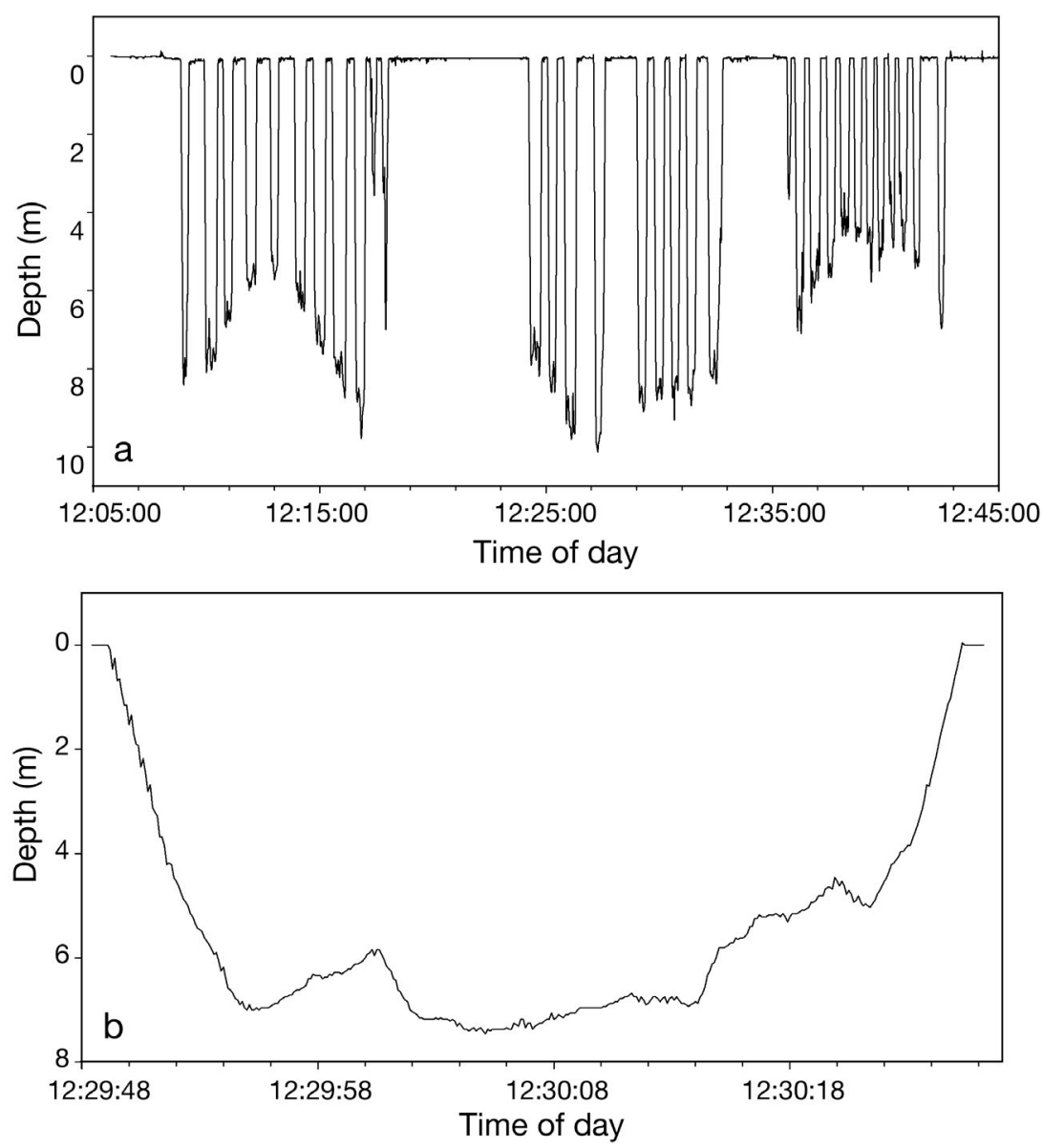

Fig. 6. Phalacrocorax bougainvillii. Dive profiles of Guanay cormorants. (a) Typical diving bouts of cormorants showing the successive dives measured at $1 \mathrm{~s}$ intervals, and (b) example of a dive profile measured at $0.1 \mathrm{~s}$ intervals showing the details of the profile. The data are indicated in local time (GMT - 5 h)

ment of these rafts and departures occurs later after the first departures of boobies. Thus, boobies may be able to leave the colony and return to the colony at night because of their more solitary behaviour, which makes them independent of the need to sight congeners to form columns and rafts as cormorants do.

\section{Foraging movements}

Although foraging trips were significantly longer in duration for Guanay cormorants than for Peruvian boobies, the foraging range and distance covered were similar between the 2 species, because cormorants spend more time sitting on the water and diving than boobies. Indeed, boobies spend a very small part of trip sitting on the water and do so mainly during foraging bouts, especially just after a dive, for a few seconds before taking off again.
Foraging bouts of the 2 species overlapped extensively and occurred mainly in the north and west of Isla Pescadores, indicating that the 2 species were foraging in the same area. Foraging bouts were absent within $5 \mathrm{~km}$ of the colony and rare within $10 \mathrm{~km}$, suggesting the presence of a zone of depletion of prey in the vicinity of the colony owing to the presence of large numbers of foraging birds commuting to and from the colony, or anchovies being deeper and not accessible. During the $3 \mathrm{~d}$ of the oceanographic cruise around the Pescadores area, anchovies were found in larger concentrations to the north and west of the island where the densities of foraging bouts were higher, although some birds did move to other areas where concentrations of anchovies were lower (Fig. 8). Foraging bouts were not concentrated in the zones of highest anchovy densities, nor in the vicinity of the island where densities were still high. This relative mismatch may be due to the fact that densities of anchovy schools, which are mobile, were carried out during a short window of time, and thus not exactly at the same time as all seabird foraging bouts. However, overall there is good overall match between the positions of the main anchovy concentrations and bird foraging bouts. Alternatively, because of the high abundance of anchovies in 2008, birds may not have tracked the highest concentrations, but instead the closest or most available. Based on the same data over the whole study period, and on the observation that from one trip to the next birds continually changed flight direction and showed an absence of persistence in flight direction, Weimerskirch et al. (2010) suggested that the location of prey patches was probably unpredictable. In addition, feeding bouts are almost never at the same site from one trip to the next for the same individual (Weimerskirch et al. 2010). These 2 observations and our data suggest that both species rely on predictable anchovy concentrations at a large scale, but that the location of schools may be less predictable at a small scale. Peruvian boobies have a tendency to leave colonies solitarily and go in a general direction from one trip to the next, often the same direction as the previous trip (Weimerskirch et al. 2010). Boobies could track the 
a
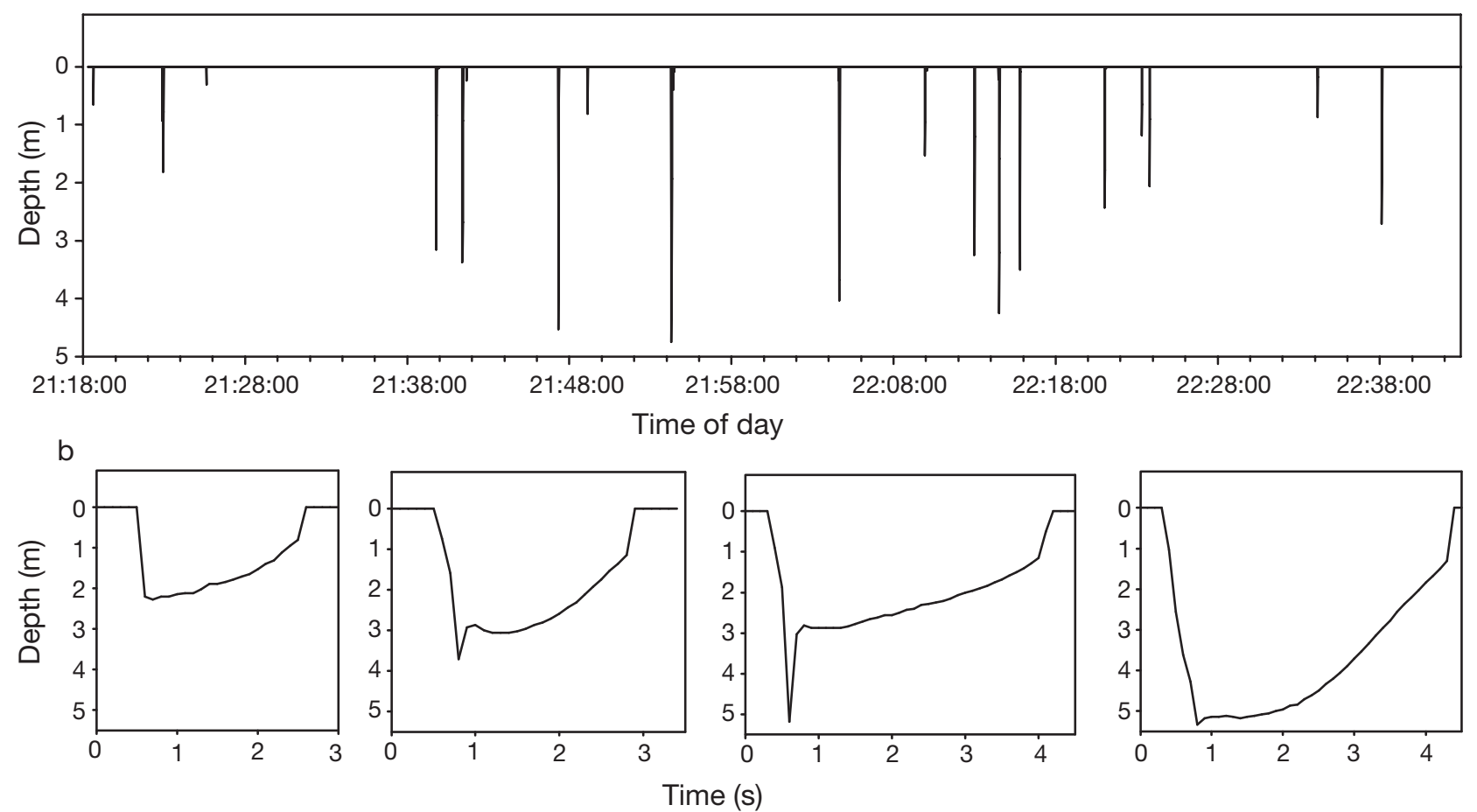

Fig. 7. Sula variegata. Diving behaviour of Peruvian boobies. (a) Typical series of shallow dives during a foraging bout recorded at 1 record $\mathrm{s}^{-1}$, and (b) 4 typical dive profiles recorded at $0.1 \mathrm{~s}$ intervals
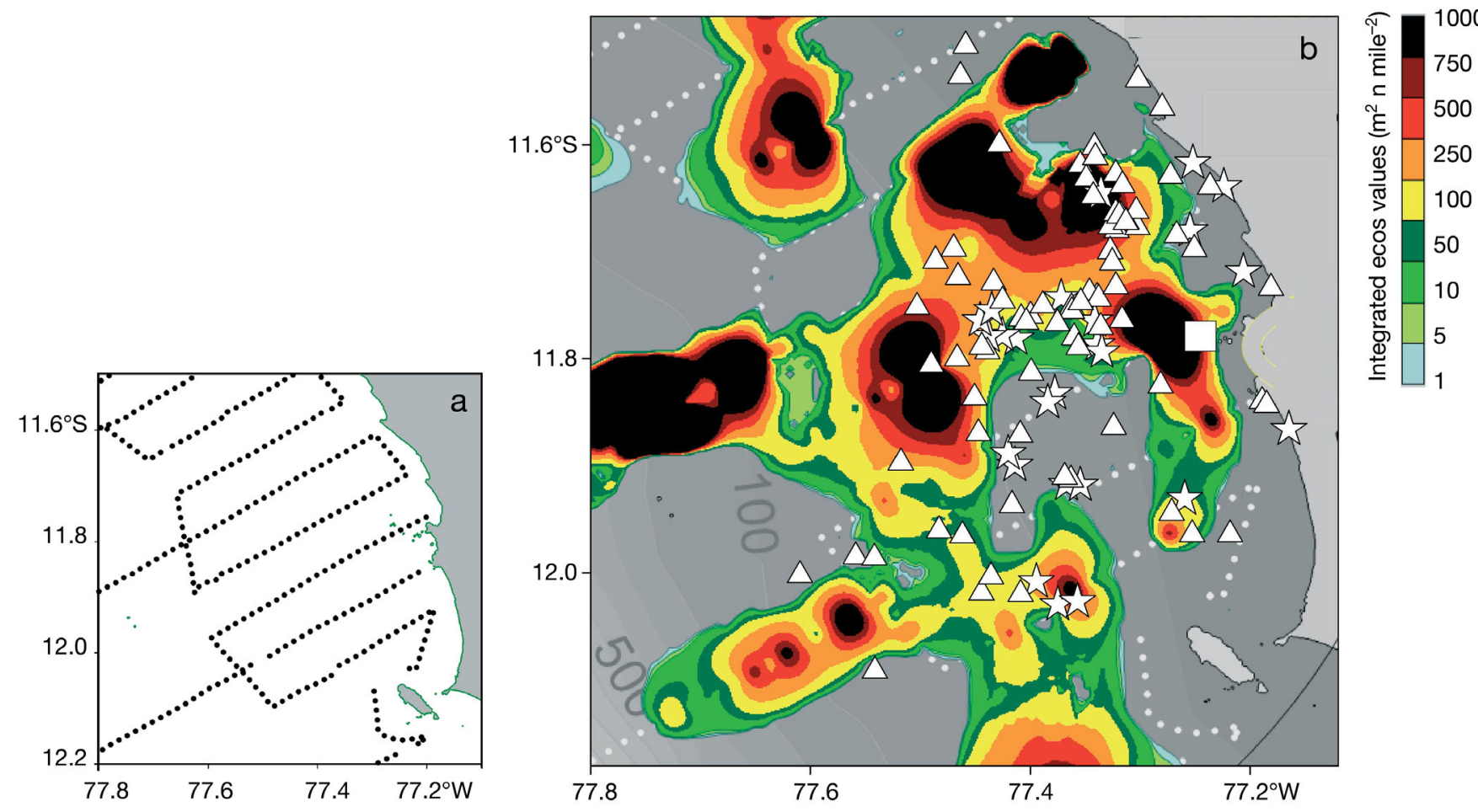

Fig. 8. Engraulis ringens, Phalacrocorax bougainvillii and Sula variegata. (a) Track of the oceanographic cruise in the Isla Pescadores area 2-5 December 2008, (b) with estimates of distribution of Peruvian anchovy schools overlaid with foraging bouts of Guanay cormorants ( $($ ) $)$ and Peruvian boobies $(\Delta)$. Seabird colony $=\square$ in (b) 
clusters of anchovy schools and locate the schools afterwards by using network foraging whereby the sight of congener movements or feeding behaviour is used as information to locate prey (Wittenberger \& Hunt 1985). Conversely, Guanay cormorants use another type of social information, the position of compass rafts off the colonies, which indicates the direction of returning columns (Weimerskirch et al. 2010).

\section{Diving behaviour}

As expected, the 2 species exhibit distinct diving behaviours: Peruvian boobies are plunge divers and Guanay cormorants surface divers (Ashmole 1971). Our study is the first to provide detailed observations on dives of Guanay cormorants. Guanay cormorants appear to be shallow-diving cormorants compared with other species of the same family that can dive regularly deeper than $100 \mathrm{~m}$ (Croxall et al. 1991). Guanay cormorants can reach maximum depths of $32 \mathrm{~m}$, but average depths for all individuals are $<10 \mathrm{~m}$. In the HCS, Guanay cormorants rely essentially on anchovies but can feed also on other prey when foraging in coastal waters (Jahncke \& Goya 1998). Depths attained by cormorants make all anchovy schools available to them within their foraging range from the colony, as indicated by the comparison of the distribution of dive depths and depths of anchovies (Fig. 5). Although they have access to all anchovy schools because of their diving abilities, they probably require social hunting for localising efficiently the schools and clusters of schools. For this reason, it is probably important for the cormorants to forage in large groups, and thus be able to use returning columns as compass rafts (Weimerskirch et al. 2010).

The analysis of the use of the intradepth zone where dives were observed indicates a clear trend for birds to dive serially to a similar depth (Tremblay \& Cherel 2000) in pelagic waters. This value is lower than for benthic divers that forage only on the seabed (Tremblay \& Cherel 2000). However, the serial diving bouts recorded indicate profitable schools at shallow depths. Guanay cormorants adjust the maximum depths attained during diving bouts and change continually, generally in the same direction, probably driving anchovies progressively deeper in the water column (Fig. 6a).

Conversely, the dive depths attained by Peruvian boobies allow them to reach only the shallowest schools or the upper parts of the deeper-occurring schools (Fig. 5). Although other species of boobies are well known to rely to a large extent on associations with subsurface predators, such as tunas or dolphins (Au \& Pitman 1986), in order to have access to prey, observations of associations with marine mammals or predatory fishes in the HCS are not common enough to account for a strict reliance of boobies on associations for feeding (Duffy 1983). Guanay cormorants may also favour the access of boobies to anchovies when they feed in large groups, but again, most observations of Peruvian boobies feeding are in monospecific groups, without association with Guanay cormorants.

\section{Comparison with other sites}

The foraging behaviour of individual Guanay cormorants has never been studied apart from some information on diving depths (Zavalaga \& Paredes 1999). Dive depths attained in our study (average, $10 \mathrm{~m}$; maximum, $32 \mathrm{~m}$ ) appear to be shallower than those recorded in southern Peru (mean, $34 \mathrm{~m}$; maximum, $74 \mathrm{~m}$ ) that used maximum depth gauges (Zavalaga \& Paredes 1999). Although maximum depth gauges may overestimate maximum depth in some cases (Burger \& Wilson 1988), it is still possible that dive depths differ greatly because anchovy schools are known to occur at various depths depending on areas and between years (Gutiérrez et al. 2007).

Peruvian boobies have been studied in the northern range of their distribution on Islas Lobos de Tierra and Lobos de Afuera (Duffy 1987, Zavalaga et al. 2010a,b) and in the southern range in Chile (Ludynia et al. 2010). Isla Pescadores lies in the middle of the range, where the largest concentrations of Peruvian anchovies and guano-producing birds occur. Foraging range of Peruvian boobies from Pescadores was short (average range, $20 \mathrm{~km}$; duration $1.4 \mathrm{~h}$ ) compared with that in the northern islands ( 25 to $30 \mathrm{~km}, 1.8$ to $2.5 \mathrm{~h}$ ) (Zavalaga et al. 2010a,b), but also compared with Isla Guañape located between those 2 areas $(45 \mathrm{~km}, 3 \mathrm{~h}$, authors' unpubl. data) where the largest colonies occur. On the other hand, the range is similar to breeding colonies located in northern Chile (Ludynia et al. 2010). Thus, it appears that foraging range is very variable between colonies and that several factors may influence it, such as local environmental conditions and associated anchovy abundance. The most important factor influencing variable foraging range may be the interannual variation in prey abundance that is extremely high in the HCS (Gutiérrez et al. 2007, Bertrand et al. 2008). Short foraging ranges 
observed in 2008 in our study may thus be mainly due to the great abundance and accessibility of anchovies during this season.

\section{Comparison with other cormorants and boobies}

Guanay cormorants are larger than other sympatric cormorant species and rely mainly on pelagic fish schools, whereas most other cormorants tend to be benthic divers. However, Guanay cormorants appear also to exploit benthic resources to a small extent when they forage along the shore. Thus, they have some degree of flexibility between pelagic and benthic foraging, as has been observed in other cormorants (Grémillet et al. 1998), which could allow them to switch to other prey when anchovies are less abundant or inaccessible, such as during El Niño years. Their equivalent in the Benguela Current is the Cape cormorant Phalacrocorax capensis, the populations of which are much smaller (Crawford et al. 2006). Guanay cormorants have nested on the same islands for several thousand of years, indicating their dependence on profitable pelagic resources. Their brood size (up to 3 eggs) does not differ from other South American species or cormorants from other upwelling systems (Nelson 2006) despite the overabundance of Peruvian anchovies during favourable years. However, the breeding success is extremely variable from one year to the next due to an extreme variability in anchovy availability (Duffy 1983).

Although of intermediate size in the family, compared with other booby species, Peruvian boobies are remarkable in their large clutch size of up to 5 eggs, rearing up to 4 chicks, whereas other species rear a single chick, and some species in favourable conditions can rear 2 chicks (Nelson 1966, 1978). The ability to fledge several chicks is, however, variable according to the year (Nelson 1978), suggesting a strong influence of food availability. During our study period, the Peruvian boobies had on average 2 chicks, suggesting relatively good conditions existed. The ability to rear large numbers of chicks is generally assumed to result from the availability of large quantities of prey, mainly anchovies (Nelson 1978). Our study shows that Peruvian boobies forage at short ranges, even shorter than for species considered to be coastal such as brown boobies Sula leucogaster (25 km on average) (Weimerskirch et al. 2009b). Thus, the great abundance and proximity of prey allows Peruvian boobies to rear a high number of chicks compared with other species in the family. However, when food is less abundant or more dis- tant, such as at other study sites, they probably rear fewer chicks or chicks in a poorer condition.

\section{Sex-specific differences}

We found little sex-specific differences in foraging characteristics in Peruvian boobies, as did Zavalaga et al. (2010b); however, they displayed a significant difference in size, females being $16 \%$ heavier and $5 \%$ larger than males (Table 1). Boobies are well known to display a reversed sexual dimorphism (Nelson 1978), and several studies have found sex differences in foraging behaviour in several species (Lewis et al. 2005, Zavalaga et al. 2007, Weimerskirch et al. $2009 a, b)$ and have suggested that they are related to the extent that sexual dimorphism exists for some foraging features, such as dive depths or foraging duration, or to different roles in parental investment. The only significant difference was the slightly longer foraging range of males versus females, a trend found in other species of boobies (Weimerskirch et al. 2005, $2009 a, b)$. These results suggest that in the case of abundant food, such as Peruvian anchovies in the HCS, sex-specific differences in foraging behaviour do not occur. However, it would be interesting to examine whether sex-specific foraging differences occur during years of low food availability.

\section{CONCLUSIONS}

Our study shows that in the HCS the 2 major guano-producing seabirds that rely mainly on Peruvian anchovy share the same feeding grounds and forage at the same time of the day, but exploit the abundant resource differently. Guanay cormorants have access to most anchovy schools through their deeper diving ability. Deeper diving may convey an advantage to the cormorants compared with Peruvian boobies, but only when prey occurs at depths deeper than the maximum dive depths of boobies. However, probably because communal diving is important for them to optimally exploit schools, they need to be in large groups and use social information obtained from rafting behaviour off colonies (Weimerskirch et al. 2010) and by forming large columns that link the prey schools and the colony (Murphy 1936). Conversely Peruvian boobies have only access to shallow schools and leave colonies solitarily to search for prey by using network foraging. Since both species share the same feeding grounds and resources, the different population trends observed 
in the 2 species may be explained by the different ways they exploit resources. The sociality of the declining Guanay cormorants that rely on communal foraging (Duffy 1983) and use of rafts and huge columns that connect food patches and colonies (Weimerskirch et al. 2010) may be a handicap for this species the populations of which have been severely depleted in the 1970s owing to El Niño and overfishing (Tovar et al. 1987) and subsequently have not recovered (Goya 2000, authors' unpubl. data). Conversely, Peruvian boobies, which were historically less abundant than Guanay cormorants, have to find the schools that are accessible to their limited diving capability and use a different search strategy based on individual searching and connection through network foraging (Weimerskirch et al. 2010).

Our study was carried during a year of high food abundance and availability, and it would be interesting to compare the foraging strategies and characteristics of the 2 species when food is less abundant, less accessible at deeper depths or more dispersed, as this resource occurs cyclically in the HCS (Gutiérrez et al. 2007, Chavez et al. 2008). Such conditions may result in a more segregated foraging pattern between species and/or between sexes within species. For this reason, long-term records of simultaneous population monitoring and foraging behaviour that encompass variable environmental conditions will be necessary to test these hypotheses.

Acknowledgements. This study was funded by Centre national de la recherche scientifique and Institut de Recherche pour le Développement and supported logistically by IMARPE (thanks to E. Goya and J. C. Marquez). We thank Proabonos (AgroRural) for giving permission to work on Isla Pescadores, the wardens of the island (L. Dávila and J. Perez) for their kind hospitality during our stay and K. Delord and C. Cotté for her help with the spatial analysis. The study is supported by and is a contribution to the TOPINEME ANR program. We thank D. C. Duffy and 2 anonymous referees for their extensive and constructive comments, and especially D. C. Duffy for his extensive editorial help.

\section{LITERATURE CITED}

Ashmole NP (1971) Seabird ecology and the marine environment. In: Farner DS, King JR (eds) Avian biology, Vol 1. Academic Press, New York, NY, p 223-286

Au DWK, Pitman RL (1986) Seabird interactions with dolphins and tuna in the Eastern Tropical Pacific. Condor 88:304-317

Bakun A, Weeks S (2008) The marine ecosystem off Peru: What are the secrets of its fishery productivity and what might its future hold? Prog Oceanogr 79:290-299

Bertrand A, Bard FX, Josse E (2002) Tuna food habits related to the micronekton distribution in French Polynesia. Mar Biol 140:1023-1037

Bertrand S, Díaz E, Niquen M (2004) Interactions between fish and fisher's spatial distribution and behaviour: an empirical study of the anchovy (Engraulis ringens) fishery of Peru. ICES J Mar Sci 61:1127-1136

Bertrand S, Burgos JM, Gerlotto F, Atiquipa J (2005) Lévy trajectories of fishers as an indicator of pelagic fish spatial distribution: the case of the Peruvian anchovy (Engraulis ringens) fishery. ICES J Mar Sci 62:477-482

Bertrand S, Dewitte B, Tam J, Díaz E, Bertrand A (2008) Impacts of Kelvin wave forcing in the Peru Humboldt Current system: scenarios of spatial reorganizations from physics to fishers. Prog Oceanogr 79:278-289

Burger AE, Wilson R (1988) Capillary-tube gauge for diving animals: an assessment of their accuracy and applicability. J Field Ornithol 59:345-354

Chavez FP, Ryan J, Lluch-Costa SE, Niquen M (2003) From anchovies to sardines and back: multidecadal in the Pacific Ocean. Science 299:217-221

Chavez F, Bertrand A, Guevara-Carrasco R, Soler P, Csirke J (2008) The northern Humboldt Current System: brief history, present status and a view towards the future. Prog Oceanogr 79:95-105

Crawford R, Goya E, Roux J, Zavalaga C (2006) Comparison of assemblages and some life-history traits of seabirds in the Humboldt and Benguela systems. Afr J Mar Sci 28: $553-560$

Croxall JP, Naito Y, Kato A, Rothery P, Briggs DR (1991) Diving patterns and performance in the Antarctic blue-eyed shag Phalacrocorax atriceps. J Zool 225:177-199

Duffy DC (1983) The foraging ecology of Peruvian seabirds. Auk 100:800-810

Duffy DC (1987) Aspects of the ecology of blue-footed and Peruvian boobies at the limits of their ranges on Isla Lobos de Tierra, Peru. Colon Waterbirds 10:45-49

Foote K, Knudsen H, Vestnes G, Maclennan D, Simmonds E (1987) Calibration of acoustic instruments for fish density estimation: a practical guide. ICES Coop Res Rep No. 144. ICES, Copenhagen

- Gerlotto F, Castillo J, Saavedra A, Barbieri MA, Espejo M, Cotel P (2004) Three-dimensional structure and avoidance behaviour of anchovy and common sardine schools in central southern Chile. ICES J Mar Sci 61:1120-1126

Goya E (2000) Abundances of guano birds and their relationship with the Peruvian anchovy fishery from 1953 to 1999. Bol Inst Mar Peru 19:125-131

> Grémillet D, Argentin G, Schulte B, Culik B (1998) Flexible foraging techniques in breeding cormorants Phalacrocorax carbo and shags Phalacrocorax aristotelis: benthic or pelagic feeding? Ibis 140:113-119

> Gutiérrez M, Swartzman G, Bertrand A, Bertrand S (2007) Anchovy (Engraulis ringens) and sardine (Sardinops sagax) spatial dynamics and aggregation patterns in the Humboldt Current ecosystem, Peru, from 1983-2003. Fish Oceanogr 16:155-168

Halsey L, Bost CA, Handrich Y (2007) A thorough and quantified method for classifying seabird diving behaviour. Polar Biol 30:991-1004

Jahncke J, Goya E (1998) Diets of the Guanay cormorant and Peruvian booby as indicators of the abundance and distribution of anchovy. Bol Inst Mar Peru 17:15-33

Jordan R (1967) The predation of guano birds on the Peruvian anchovy (Engraulis ringens Jenyns). CCOFI Rep 11: 105-109 
Kato A, Ropert-Coudert Y, Grémillet D, Cannell B (2006) Locomotion and foraging strategy in foot-propelled and wing-propelled shallow-diving seabirds. Mar Ecol Prog Ser 308:293-301

Kooyman G, Kooyman T (1995) Diving behavior of emperor penguins nurturing chicks at Coulman Island, Antarctica. Condor 97:536-549

Lewis S, Schreiber EA, Daunt F, Schenk GA and others (2005) Sex-specific foraging behaviour in tropical boobies: Does size matter? Ibis 147:408-414

Ludynia K, Garthe S, Luna-Jorquera G (2010) Distribution and foraging behaviour of the Peruvian booby (Sula variegata) off northern Chile. J Ornithol 151:103-111

Maclennan DN, Fernandes PC, Dalen J (2002) A consistent approach to definitions and symbols in fisheries acoustics. ICES J Mar Sci 59:365-369

Marchal E (1990) Utilisation de l'acoustique dans l'étude des structures agrégatives des organismes pélagiques (couches, bancs). Oceanis 16:91-96

Murphy RC (1936) Oceanic birds of South America. Am Mus Nat Hist, New York, NY

> Nelson JB (1966) Clutch size in the Sulidae. Nature 210: 435-436

Nelson J (1978) The Sulidae: gannets and boobies. Oxford University Press, Oxford

Nelson JB (2006) Pelicans, cormorants, and their relatives: the Pelecaniformes. Bird families of the world. Oxford University Press, Oxford

Pianka E (1969) Sympatry of desert lizards (Ctenotus) in Western Australia. Ecology 50:1012-1030

R Development Core Team (2006) A language and environment for statistical computing. Vienna, Austria

Seaman DE, Powell RA (1996) An evaluation of the accuracy of kernel density estimators for home range analysis. Ecology 77:2075-2085

Simmonds EJ, Maclennan DN (2005) Fisheries acoustics: theory and practice. Wiley-Blackwell, Oxford

Tovar H, Guillén V, Nakama ME (1987) Monthly population size of three guano bird species of Perú, 1953 to1992. In: Pauly D, Tsukayama I (eds) The Peruvian Anchoveta and its upwelling ecosystem: three decades of change. ICLARM Rev Stud, Manila

> Tremblay Y, Cherel Y (2000) Benthic and pelagic dives: a new foraging behaviour in rockhopper penguins. Mar Ecol Prog Ser 204:257-267

> Wanless S, Finney SK, Harris MP, McCafferty DJ (1999) Effect of the diel light cycle on the diving behaviour of two bottom feeding marine birds: the blue-eyed shag Phalacrocorax atriceps and the European shag P. aristotelis. Mar Ecol Prog Ser 188:219-224

- Watanuki Y, Daunt F, Takahashi A, Newell M, Wanless S,

Editorial responsibility: Rory Wilson,

Swansea, UK
Sato K, Miyazaki N (2008) Microhabitat use and prey capture of a bottom-feeding top predator, the European shag, shown by camera loggers. Mar Ecol Prog Ser 356: 283-293

Weimerskirch H, Le Corre M, Ropert-Coudert Y, Kato A, Marsac F (2005) The three dimensional flight of redfooted boobies: adaptations to foraging in a tropical environment. Proc R Soc Lond B Biol Sci 272:53-61

Weimerskirch H, Le Corre M, Gadenne H, Pinaud D, Kato A, Ropert-Coudert Y, Bost C (2009a) Relationship between reversed sexual dimorphism, breeding investment and foraging ecology in a pelagic seabird, the masked booby. Oecologia 161:637-649

Weimerskirch H, Shaffer S, Tremblay Y, Costa D and others (2009b) Species- and sex-specific differences in foraging behaviour and foraging zones in blue-footed and brown boobies in the Gulf of California. Mar Ecol Prog Ser 391: $267-278$

Weimerskirch H, Bertrand S, Silva J, Marques JC, Goya E (2010) Use of social information in seabirds: compass rafts indicate the heading of food patches. PLoS ONE 5: e9928

Wittenberger JF, Hunt GL Jr (1985) The adaptive significance of coloniality in birds. In: Farner DS, King JR, Parkes KC (ed) Avian biology, Vol 8. Academic Press, New York, NY, p 1-77

Wood AG, Naef-Daenzer B, Prince PA, Croxall JP (2000) Quantifying habitat use in satellite-tracked pelagic seabirds: application of kernel estimation to albatross locations. J Avian Biol 31:278-286

Worton BJ (1995) Using Monte Carlo simulation to evaluate kernel-based home range estimators. J Wildl Manag 59: 794-800

Zavalaga CB, Paredes R (1999) Foraging behaviour and diet of the guanay cormorant. S Afr J Mar Sci 21:251-258

Zavalaga CB, Benvenuti S, Dall'Antonia L, Emslie SD (2007) Diving behavior of blue-footed boobies Sula nebouxii in northern Peru in relation to sex, body size and prey type. Mar Ecol Prog Ser 336:291-303

Zavalaga C, Halls J, Dell'Omo G (2010a) Marine habitat use of Peruvian boobies: a geographic and oceanographic comparison between inshore and offshore islands. ICES J Mar Sci 67:940-951

Zavalaga C, Halls J, Mori G, Taylor S, Dell'Omo G (2010b) At-sea movement patterns and diving behavior of Peruvian boobies Sula variegata in northern Peru. Mar Ecol Prog Ser 404:259-274

Zavalaga CB, Dell'Omo G, Becciu P, Yoda K (2011) Patterns of GPS tracks suggest nocturnal foraging by incubating Peruvian pelicans (Pelecanus thagus). PLoS ONE 6: e19966

Submitted: July 26, 2011; Accepted: April 8, 2012

Proofs received from author(s): June 22, 2012 